Asian J. Med. Biol. Res. 2020, 6 (2), 351-358; doi: 10.3329/ajmbr.v6i2.48083

\author{
Asian Journal of \\ Medical and Biological Research \\ ISSN 2411-4472 (Print) 2412-5571 (Online) \\ www.ebupress.com/journal/ajmbr
}

\title{
Article \\ Socio-economic status of fisher community at Nijhum Dwip
}

\author{
Hassan Shafkat Siam, Md. Robiul Hasan* and Tasnim Sultana \\ Department of Fisheries and Marine Science, Noakhali Science and Technology University, Noakhali-3814, \\ Bangladesh
}

${ }^{*}$ Corresponding author: Md. Robiul Hasan, Department of Fisheries and Marine Science, Noakhali Science and Technology University, Noakhali-3814, Bangladesh. E-mail: rhasan_rony@yahoo.com

Received: 03 June 2020/Accepted: 29 June 2020/ Published: 30 June 2020

\begin{abstract}
Nijhum dwip is a well-known island in which local people are mostly dependent on fisheries resources. The island is located in Hatiya Upazila under Noakhali district, Bangladesh. The present study attempted to investigate the socio-economic condition of fishers on this island. We randomly selected 50 fishers for an interview in the field survey. From the investigation, we found that $94 \%$ of fishers were male, and $6 \%$ were female. A large portion was Muslim (90\%), and the rest was Hindu (10\%). About $91 \%$ were found married. Nuclear families were more (59\%) common compared to joint families. Among school-going children, $57 \%$ of boys and $43 \%$ of girls were dropouts. Eighty-eight per cent of dwellings were full katcha while semipacca were $12 \%$ and all the family are lack of electricity facilities. Different types of the net including the set bag net, tong jal, current jal, tanajal etc. were found on this island. They used motorboats, and engine power ranges from 8 to $22 \mathrm{hp}$ for fishing. A group of fishermen caught fish averagely $35-80 \mathrm{~kg}$ per day. A portion of them being consumed for households and the rest of them are usually sold. The monthly average income was around BDT7000-8000. Fifty-six per cent of the fishermen borrowed money from money lenders and 44\% from the NGOs. Our findings suggest that GOs and NGOs should come forward for the betterment of socio-economic condition through increasing educational opportunities, loan facilities and electricity facilities and sustainable livelihood in the present study area.
\end{abstract}

Keywords: Nijhum dwip; livelihood; socio-economic; fisher community

\section{Introduction}

Bangladesh is called as the land of rivers where numerous rivers are connected with marine water resources (Hutton and Haque, 2004). Consequently, fisheries is one of the most important sectors that contributes to the national currency of Bangladesh by creating employment opportunity, reducing poverty, providing a source of protein and exporting as an important food item (Shamsuzzaman et al., 2017). People of Bangladesh appears to fulfil approximately 60 per cent of the national animal protein demand and nineteen per cent of the total protein demand from eating fish daily (DOF, 2016). Besides, the fisheries sector contributes about $2.46 \%$ of the total export earnings, $4.39 \%$ to GDP and $22.76 \%$ to the agriculture sector (FRSS, 2016). In the year of 2014-2015, the total fish production was 3.68 million metric tons, and estimated earning was approximately seventy per cent less than the per capita earning (FRSS, 2016). In addition, about 12 million people actively or passively associated with fishing for their livelihood. It provides 1.78 million people full-time and part-time employment facilities (DOF, 2015).

Consequently, rural subsistence fishermen families are mostly dependent on fish as primary food through which they are meeting protein and other essential minerals demand (DOF, 2014). Although fisherman lives matter, they are a vulnerable community who lives even below the poverty level. Several studies found that the livelihood standard appears to be decreasing with being time passed in Bangladesh. While most studies occurred in riverside village or upazilla (Ahmed and Hossain, 1999; Shahjahan et al., 2001; Hasan et al., 2011; Bhuyan and Islam, 2016; Uddin et al., 2020), there are a number of island/dwip areas that have been paid little attention regarding socio-economic studies of local fishermen. 
Nijhum Dwip is considered to be a small island, which has been located in Hatiya Upazila. Nijhum Dwip is situated in Noakhali District in Bangladesh. The total area of the island covers 163.45 square km. Among them, the land is 38.65 square $\mathrm{km}$ and water are 124.81 square $\mathrm{km}$. The population in Nijhum Dwip in 2016 was more than 25,000. Their main occupations are cultivation, fishing and livestock farming (Iftekhar and Takama, 2008; Wahiduzzaman and Hasan, 2020). Although a large portion of people is involved in fishing activities, the study of the socio-economic conditions of fishermen community of this island is scarce in the literature. Therefore, we attempted to know about the socio-economic status of the fishing community of this island to develop a sustainable management system for improving their livelihood.

\section{Materials and Methods}

\subsection{Study area}

This study was carried out in Nijhum Dwip, Hatiya, Bangladesh (Figure 1). The study period was from October to December 2019.

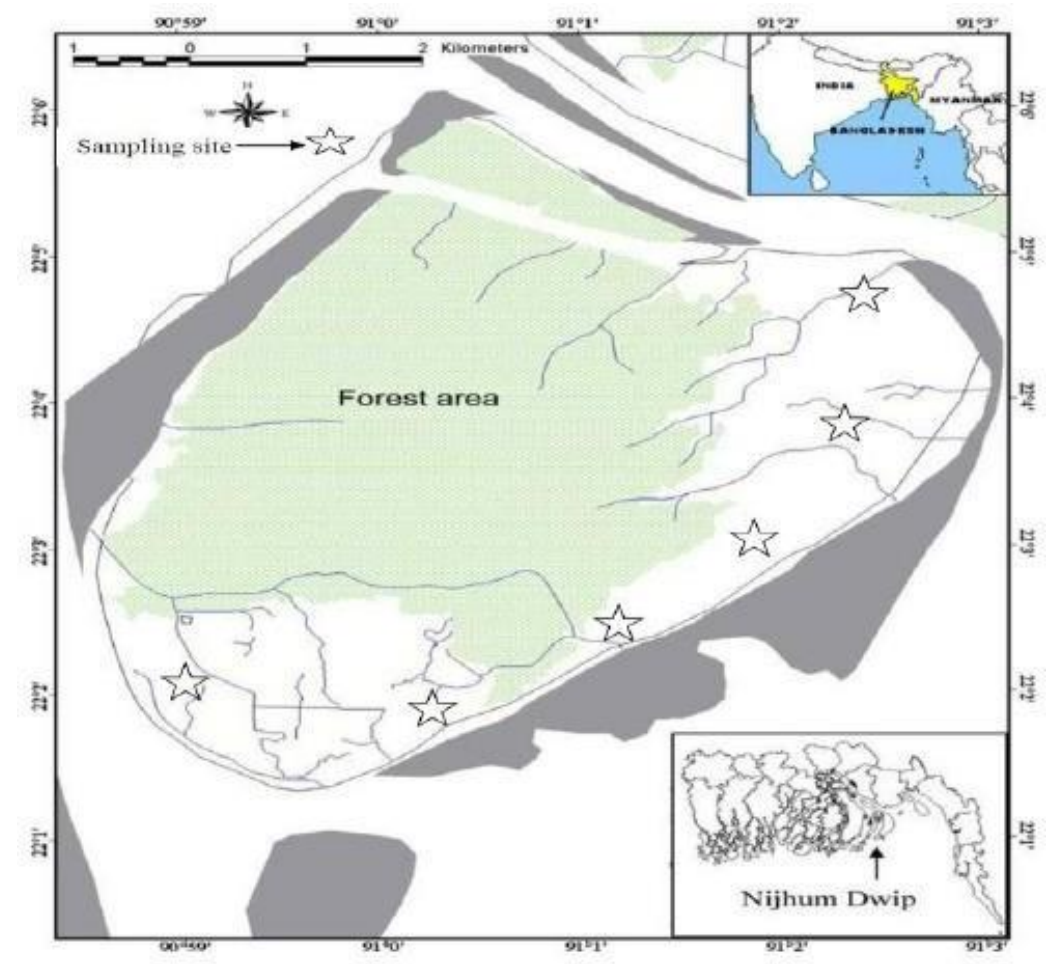

Figure 1. Map of Nijhum Dwip.

\subsection{Data collection}

A large number of fisherman were known to be engaged in fish catching in Nijhum Dwip. These fishermen are the target groups of the present study. The sample of 50 households has been selected proportionately of Nijhum Dwip by using random sampling.

For this study, mainly quantitative data were collected, but a few qualitative data were also collected. Quantitative data were collected to provide information on sex, age, type of religion, family conditions, housing conditions, literacy of fishers and their family members, household assets, electricity facilities, other occupations, sanitation, land ownership, drinking water facility, health condition, and financial conditions. These data are actually primary data, which were collected through a questionnaire interview of fishermen in the study area.

\subsection{Data analysis}

Collected data were set in tabular form and analysed using MS Excel. Afterwards, graphical structures were visualized from the analysis to get a clear understanding of the socio-economic status of the fisher community at the target area. 


\section{Results and Discussion}

Our results showed that fishermen in the study are completely dependent on fishing. So, we included a range of socio-economic characteristics such as sex, age, type of religion, family conditions, housing conditions, literacy of fishers and their family members, household assets, electricity facilities, other occupations, sanitation, land ownership, drinking water facility, health condition, and financial conditions for a clear understanding of our research objectives.

\subsection{Sex}

Usually, women live in the house and use to do household works. They cannot go outside for fishing primarily due to social barriers and danger of trafficking. However, such barriers were not found for male. In the study area, fish drying, processing etc. were suitable for women.

\subsection{Age group}

We found six categories of the age group in the study area (21-30, 31-40, 41-50, 51-60 and 61-70 years) (Figure 2). The maximum number of fishers were between 31 and 40 age group, including middle age group indicating that they are dominant over other age groups, probably because of their strong physical health (Figure 2). Similarly, Ahamed (1996) and Ahmed and Hossain (1999) found that the dominant fishermen group were aged less than 40 years.

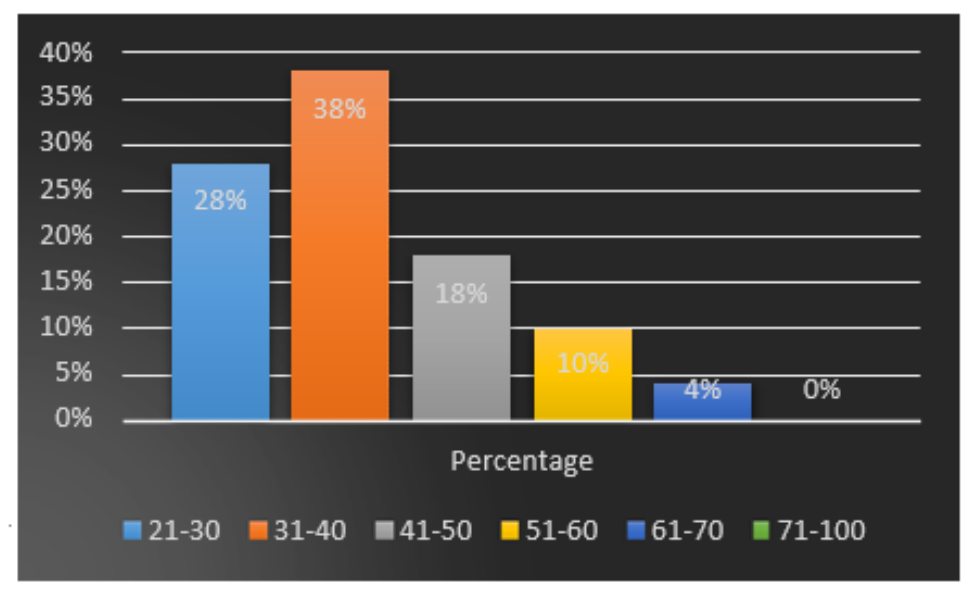

Figure 2. Age group of fishermen.

\subsection{Religion}

The study found that people are mostly Muslim. No other religion of fisherman were not found during the survey out of 50 fishermen. Similarly, Chantarasri (1994) found that the maximum number of fishermen were Muslim. In addition, Ahmed and Hossain (1999) found that approximately 68\% of fishermen were Muslim and minority were Hindu (32\%) at Sundarban. In contrast, similar studies conducted in the Tangail District found the majority of fishermen were Hindu (57\%) (Ahamed 1996).

\subsection{Marital status}

The study revealed that almost $88 \%$ of fishermen were married while the unmarried fishermen covered $12 \%$. There were no divorced persons found in this survey.

\subsection{Family condition}

The study revealed that the number of the joint family was more (68\%) compared to the nuclear family (32\%) (Figure 3). Similar evidence was also found by Rokanuzzaman (2004). 


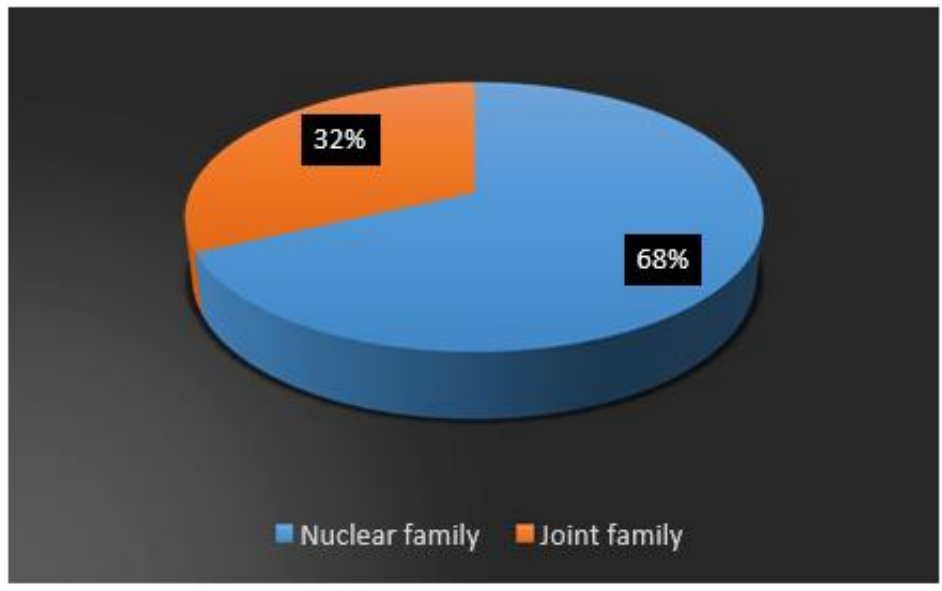

Figure 3. Family type of fishing community.

\subsection{Housing condition}

Two main types of house were found in the study area such as katcha (those houses having muddy floor with bamboo and talli or tin) and semi-pacca (made of wood or/and tin). The study revealed that $84 \%$ of housing structures were katcha, 16\% were semi-pacca, and pacca were not found (Figure 4). Similarly, Shamima (2000) showed that $94 \%$ of fishermen house was made up of mud (i.e., katcha). Besides, Ahmed and Hossain (1999) showed that fishermen usually live in poor housing conditions, and those houses often made with mud and a type of weed leaves.

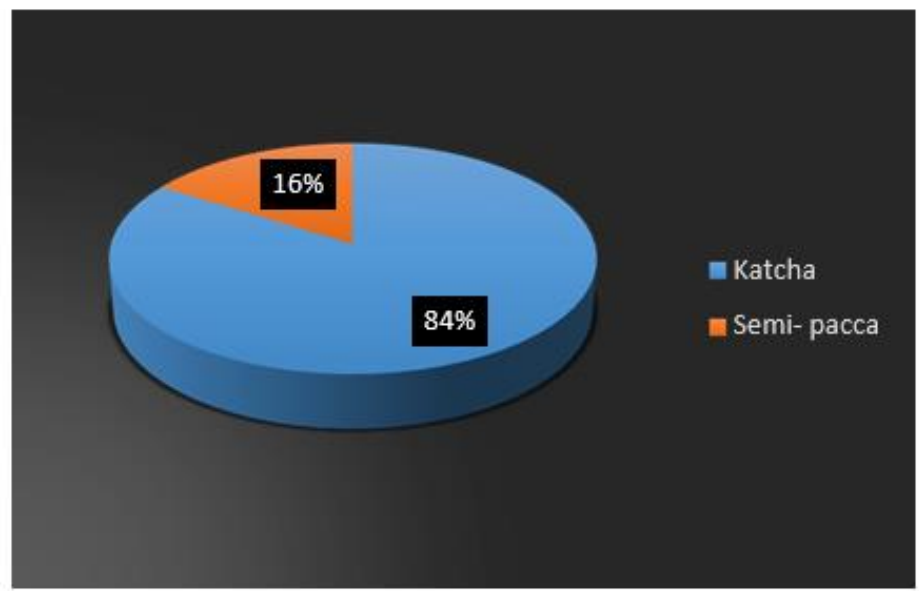

Figure 4. Housing condition of fishermen.

\subsection{Use of electricity}

The study area is a distinct island. So the electricity was not available here. The island is not developed yet. People use power generator in the market or bazar area for a short period $(7 \mathrm{pm}-11 \mathrm{pm})$. The solar panel is used in the house and all over the island. Mainly solar energy is the main source of electricity. However, Shamima (2000) reported that $20 \%$ of fishermen enjoy electricity facility. Besides, Hossain (2009) showed that $95 \%$ of fishermen had access to electricity, and 5\% did not get the facility of using electricity.

\subsection{Educational status}

The literacy rate was not up to the standard in the study site. We found that $6 \%$ of the fishermen had primary level education (i.e., class five), $22 \%$ of fishers can sign only, and $72 \%$ having no institutional education (Figure 5). Similarly, Ahamed (1996) found literacy rates of fishers were $23 \%$ in Tangail. 


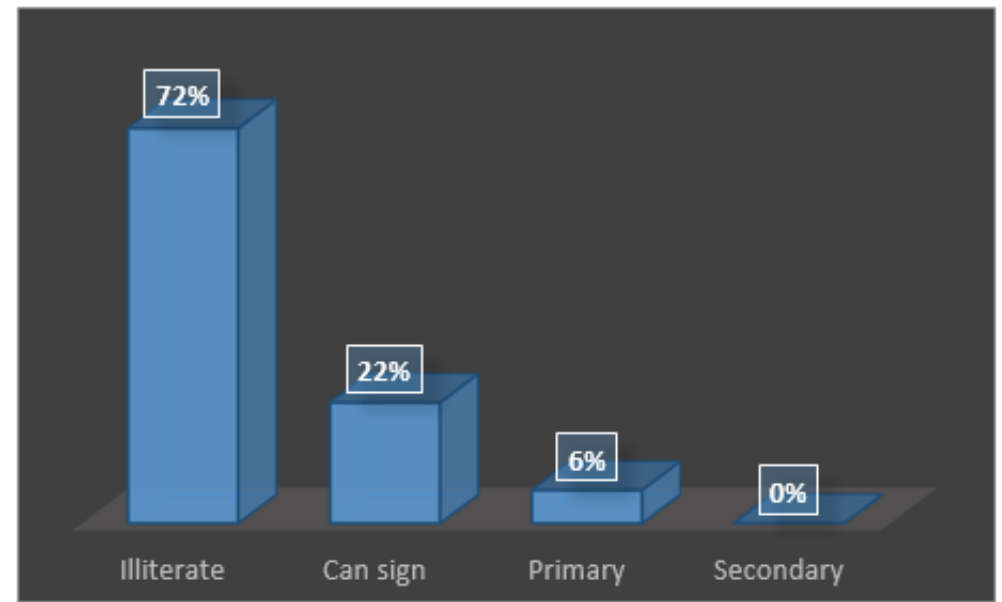

Figure 5. Educational status of fishermen.

\subsection{School going and dropout children of fishermen}

The study showed that the number of boys was more school-oriented than girls. However, the dropout rate was also higher for boys (63\%) compared to girls (37\%). Several causes were identified behind school dropout including illiteracy, unconsciousness of family members, children often involved in earning, social and other problems.

\subsection{Secondary occupation}

Occupation can be an activity that the people intends to eam for daily livelihood. In the surveyed area, $87 \%$ of fishermen were involved solely in fishing while $9 \%$ in fishing with agriculture and $4 \%$ in fishing with other professions.

\subsection{Assets}

We found fishermen have agricultural lands, fishing gears, poultry and livestock as their significant assets.

\subsection{Agricultural land ownership}

During the survey, it was found that how the fishermen owned much agricultural land. Agricultural land is one of the most productive assets of them who lived in the villages. It was found that $78 \%$ of fishers had no property except their house, $16 \%$ had land below 50 decimal, and $6 \%$ had area above 50 decimal (Figure 6). In contrast, Kader et al. (2018) found that the highest number of fishermen (60\%) had above 50 decimal lands.

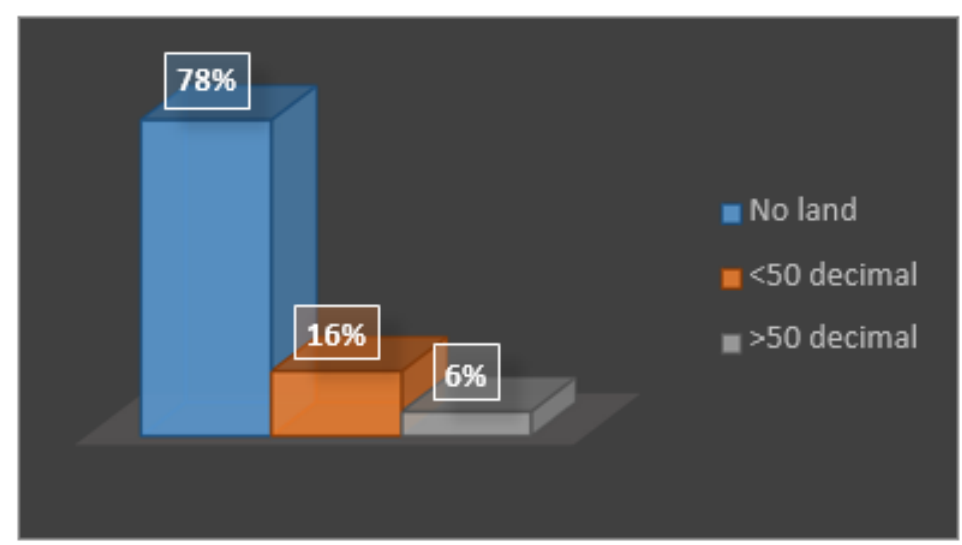

Figure 6. Agricultural land ownership of fishermen. 


\subsection{Poultry and livestock}

The results showed that $74 \%$ of fishermen involved in poultry and livestock farming, including cow/goat/hen/duck. About $26 \%$ of fishermen had no animal and poultry.

\subsection{Food and nutrition}

Major food item of the fishermen was fish, meat, dal, egg and vegetables. It was found that the consumption of fish was highest, but the use of meat was minimum in a month. During fishing, the fishermen keep some fish for themselves. In addition, while selling some fishes were left over.

\subsection{Sanitation practice}

The present study reveals that fisherman has been facing sanitary problems. In the study areas, it was found that $88 \%$ of people use katcha latrine, and only $12 \%$ use sanitary latrine (Figure 7). However, other studies found that fishermen used no sanitary toilet (CPP, 1966).

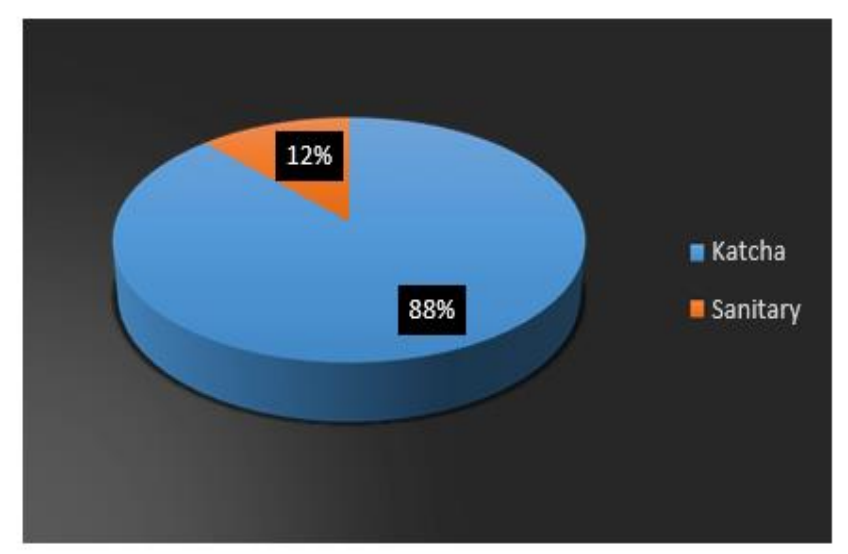

Figure 7. Sanitation practice of fishermen.

\subsection{Drinking water facilities}

There are many tube-wells in these fishing villages. So fresh drinking water is not a problem. Mainly tube-well water are the main source of drinking and other household activities. On the other hand, in another study, Ahmed and Hossain (1999) found that pond water may be the alternative source for household activities instead of tube-well water in the coastal area.

\subsection{Income}

It was found that the daily income of fishermen ranging from BDT 200 to 300 and this derived from selling fish. Thus, the average was found BDT250/day. From this income, fishermen often raise funds for future household purposes. The monthly average income in this study area was found around BDT 6000-8000 per head. In addition, the study showed that $64 \%$ of fishermen yearly income between BDT 80,000 and 1,00,000 (Figure 8). Also, $18 \%$ fishermen yearly income between BDT 70,000 and 80,000, 11\% fishermen yearly income below BDT 60,000 and 7\% fishermen yearly income more than BDT 2,00,000 (Figure 8).

\subsection{Economic condition}

The financial condition of the fishermen was somewhat poor. Most of them face difficulty to have meals three times a day. They spend money on agriculture production and livestock farming and a few for dairies. They often lend money due to lacking enough capital. The main sources of their loan are NGO's and from local mohajon, which is called dadon. Fishers also lend money for food, medical, marriage and business purpose. 


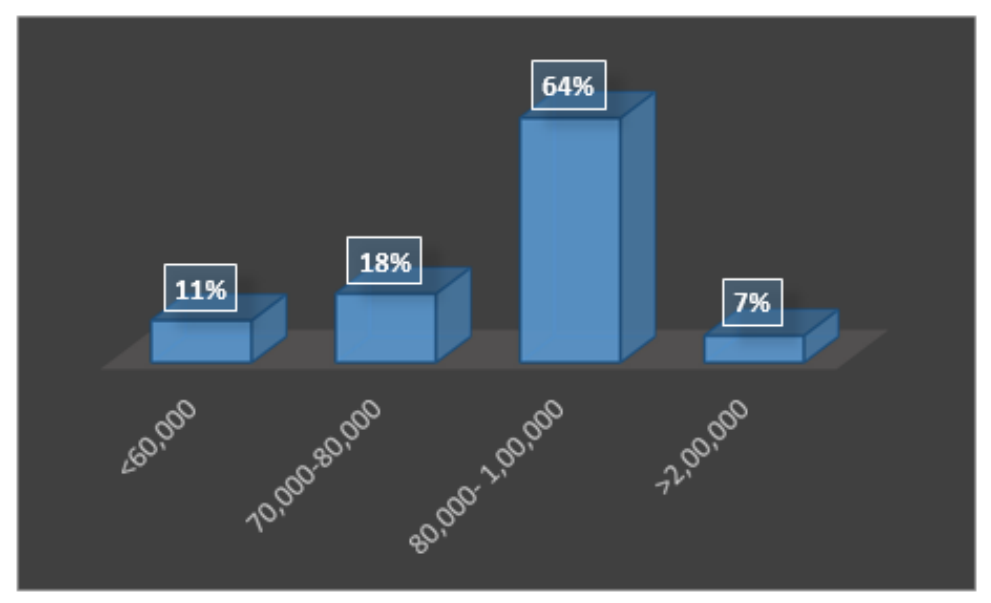

Figure 8. Yearly income status of fishermen.

\section{Conclusions and Recommendations}

The present study area is a very remote area having very little or no communication and development. From the above discussion, we can say that the fishermen community is poorer and disadvantageous compared to the other people. There is no alternate income source of fishers except for fishing. As a result, overall socioeconomic development is not up to the mark. In addition, while fishermen have been facing several problems according to our current findings, there is a necessity to implement guidelines and regulations for the community people to uphold their socio-economic status.

Consequently, fishing regulations should be strictly implemented. Credit schemes with low-interest rate from a commercial and rural bank in co-operation with the extension service of the Fisheries Department might be an alternative solution. Proper training could be provided to the fishermen regarding sanitation, education and health conditions by GO and NGOs.

\section{Acknowledgements}

We are thankful to the fisher community in the study area to accomplish our study objectives.

\section{Conflict of interest}

None to declare.

\section{References}

Ahamed NU, 1996. Report of the fishermen's socio-economic survey. Fisheries survey and Monitoring program, Department of fisheries, Tangail.

Ahmed N and M Hossain, 1999. A study on socio-economic aspects of coastal fishermen of Bangladesh. Progress. Agric., 10: 151-155.

Bhuyan S and S Islam, 2016. Present status of socio-economic conditions of the fishing community of the Meghna River adjacent to Narsingdi District, Bangladesh. J Fish Livestock Prod., 4: 1000192.

Chantarasri S, 1994. Integrated Resources Development of the Sundarbans Reserved Forest. The draft reports on Fisheries Resources Management for the Sundarbans Reserved Forest, Khulna, Bangladesh (BGD/84/OSG) FAO- UNDP., pp. 5-171.

CPP, 1966. Socio-economic profile of the professional fishermen and institutional organization. Final report. Bangladesh Water Development Board. Tangail, pp. 11-45.

DOF, 2016. National fish week, compendium (In Bengali). Dhaka: Department of Fisheries, Ministry of Fisheries and Livestock, Government of Bangladesh.

DOF, 2015. National fish week, compendium (In Bengali). Dhaka: Department of Fisheries, Ministry of Fisheries and Livestock, Government of Bangladesh.

DOF, 2014. National fish week, compendium (In Bengali). Dhaka: Department of Fisheries, Ministry of Fisheries and Livestock, Government of Bangladesh.

FRSS, 2016. Fisheries resources survey system (FRSS), fisheries statistical report of Bangladesh. Department of Fisheries, 32:1e57. 
Hasan MR, MA Miah, MA Dowla, MI Miah and SAA Nahid, 2011. Socio-economic condition of fishermen of the Jamuna river in Dewangonj Upazila under Jamalpur district. J. Bangladesh Soc. Agric. Sci. Technol., 8: $159-168$.

Hossain MA, 2009. Socio-economic condition of fish farmers in Jessore District, Khulna. B.Sc. thesis. Fisheries and Marine Resource Technology Discipline, Khulna University, Khulna, No. 1-20 pp.

Hutton D and CE Haque, 2004. Human vulnerability, dislocation and resettlement: adaptation processes of river-bank erosion-induced displacees in Bangladesh. Disast., 28: 41-62.

Iftekhar MS and T Takama, 2008. Perceptions of biodiversity, environmental services, and conservation of planted mangroves: a case study on Nijhum Dwip Island, Bangladesh. Wetl. Ecol. Manag., 16:119-137.

Kader MA, AH Choudhury, G Mustafa, MR Nabi, MM Billah, AA Asif and AAM Siddiqui, 2018. Socioeconomic uplifting analysis of esbn fishery of the coastal villages, Kumira and Kattoli, Chittagong, Bangladesh. Int. J. Res. Granth., 6: 248-263.

Rokanuzzaman M, 2004. Impact of community based fisheries management project on livelihoods of a fishing community in a haor area of Sunamgonj district. MS Thesis. Department of Aquaculture,BAU, Mymensingh. pp. 50-53.

Shahjahan M, MI Miah and MM Haque, 2001. Present status of fisheries in the Jamuna River. Pakistan J. Biol. Sci., 4: 1173-1176.

Shamima SH, 2000. Socio-economic condition of fishing community: Gallamary fish market, Khulna. B.Sc. thesis. Fisheries and Marine Resource Technology Discipline, Khulna University, Khulna, No. 11-44 pp.

Shamsuzzaman MM, MM Islam, NJ Tania, MAA Mamun, PP Barman and X Xu, 2017. Fisheries resources of Bangladesh: present status and future direction. Aquac. Fish., 2: 145-156.

Uddin MK, MR Hasan, SK Paul and T Sultana, 2020. Socio-economic condition and livelihood status of the fisherman community at Muradnagar Upazila in Cumilla. Fish. Aquac. J., In press.

Wahiduzzaman M and MR Hasan, 2020. Fishing gear and craft used at Nijhum Dwip under Hatiya Upazila of Noakhali District, Bangladesh. World J. Fish. Mar. Sci., 12: 1-5. 